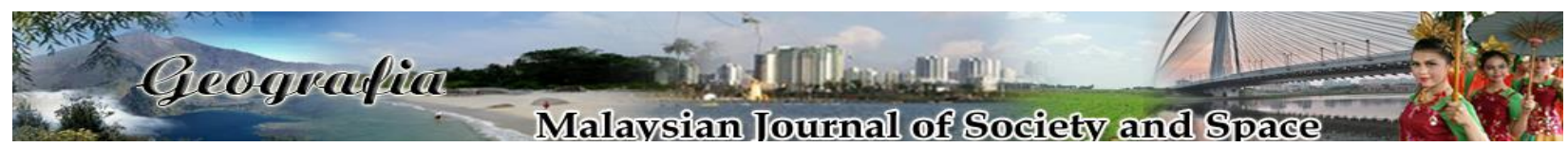

\title{
Perubahan politik dalam pilihan raya umum (PRU) ke-14, 2018 di Malaysia
}

\author{
Junaidi Awang Besar \\ Program Geografi, Pusat Pembangunan, Sosial dan Persekitaran, \\ Fakulti Sains Sosial dan Kemanusiaan, Universiti Kebangsaan Malaysia \\ Correspondence: Junaidi Awang Besar (email: jab@ukm.edu.my)
}

Received: 15 November 2019; Accepted: 22 November 2019; Published: 25 November 2019

\begin{abstract}
Abstrak
Pilihan Raya Umum (PRU) ke-14, 2018 telah berlangsung pada 9 Mei 2018 dengan aman dan tenang namun penuh 'dramatik'. Keputusan politik rakyat Malaysia tersebut menunjukkan bahawa buat pertama kali dalam sejarah politik pilihan raya di negara ini bahawa berlakunya perubahan politik iaitu Barisan Nasional (BN) telah tewas kepada pakatan pembangkang yang menggunakan logo Parti Keadilan Rakyat (PKR) atau dengan gelaran Pakatan Harapan (PH) dan Parti Warisan Sabah dengan 122 kerusi Parlimen, 79 kerusi Parlimen dimenangi BN serta PAS yang bertanding bersendirian hanya mendapat 18 kerusi Parlimen. Keputusan PRU 2018 yang dilihat 'luar biasa' ini menunjukkan bahawa wujudnya satu 'gelombang' atau kebangkitan rakyat/pengundi yang dilihat sebagai 'silent voters' telah meranapkan penguasaan BN terhadap Kerajaan Malaysia sejak 63 tahun yang lalu. Justeru adalah menjadi tujuan penulisan artikel ini untuk menganalisis perubahan politik dalam PRU 2018. Metod yang digunakan dalam penulisan artikel ini adalah rujukan data primer iaitu keputusan PRU 2018 manakala rujukan data sekunder adalah daripada sumber bercetak dan juga maklumat atas talian untuk mengukuhkan analisis mendalam bagi penulisan artikel ini. Dapatan dan perbincangan kajian menunjukkan bahawa tekad untuk jatuhkan BN, faktor ekonomi/beban/kos sara hidup rakyat, kerosakan imej atau personaliti/peribadi pemimpin dan parti, kesepaduan Pakatan Harapan, peranan media sosial, pengaruh Tun Dr. Mahathir, pengaruh 1.4 juta pengundi baru/muda dan perang persepsi telah berjaya membentuk satu gelombang yang akhirnya telah menumbangkan BN dalam PRU 2018. Justeru keputusan PRU tersebut menunjukkan bahawa ilmu politik bersifat dinamik dan berseni serta tiada yang mustahil dalam sesuatu proses politik.
\end{abstract}

Kata kunci: ekonomi, gelombang, parlimen, pemimpin, perubahan politik, pilihan raya umum 


\title{
Political change in the 14th general election (GE), 2018 in Malaysia
}

\begin{abstract}
The 14th General Election, 2018, took place on May 9, 2018 in a peaceful and calm but 'dramatic' way. The Malaysian political decision shows that for the first time in the country's electoral political history political change the Barisan Nasional (BN) has lost its way to the opposition coalition using the Parti Keadilan Rakyat (PKR) logo or the Pakatan Harapan (PH) and the Parti Warisan Sabah with 122 parliamentary seats, 79 parliamentary seats won by the BN and PAS stand-alone won only 18 parliamentary seats. The 'extraordinary' 2018 general election results show that the existence of a 'wave' or voter turnout that has been seen as 'silent voters' has undermined BN's control over the Malaysian Government for the past 63 years. Thus, the purpose of this article is to analyze the political changes in the 2018 General Election. The methods used in the writing of this article are the primary data reference of the 2018 General Elections while the secondary data references are from printed sources as well as online information to strengthen the in-depth analysis of this article. The findings and discussion of the study show that the determination to bring down the BN, economic factors/burdens/cost of living of the people, image or personality/personal damage of leaders and parties, Pakatan Harapan unity, social media role, influence of Tun Dr. Mahathir, the influx of 1.4 million new/young voters and the war of perception, has created a wave that eventually toppled BN in the 2018 general election. Thus the general election results show that political science is dynamic and artistic and that nothing is impossible in a political process.
\end{abstract}

Keywords: economy, wave, parliament, leaders, political change, general election

\section{Pengenalan}

Pilihan Raya Umum (PRU) ke-14, 2018 merupakan PRU yang paling sengit dalam sejarah pilihan raya di negara ini. Hal ini demikian kerana kedua-dua pihak sama ada Barisan Nasional (BN) mahupun pakatan parti pembangkang yang kini mempunyai dua blok iaitu Pakatan Harapan (PH) dan Gagasan Sejahtera (GS) yang dipimpin oleh Parti Islam SeMalaysia (PAS) mempunyai peluang yang seimbang. Dalam ilmu politik yang serba mungkin, dinamik dan penuh 'seni' atau strategi/taktikal ini, mereka cuba sedaya upaya berkempen untuk memenangi hati dan nurani 14.9 juta pengundi di negara ini. Hasil PRU 2018 menunjukkan bahawa berlakunya satu 'gelombang' besar yang menolak BN di peringkat Parlimen/Persekutuan dan di 10 negeri kecuali di Perlis dan Pahang. PH berjaya menewaskan BN dan PAS pada peringkat kerusi Parlimen dengan 122-79-18. PH kekal di negeri Selangor dan Pulau Pinang serta berjaya menawan Johor, Negeri Sembilan, Melaka; Kedah, Perak dan Sabah ditawan PH dengan 'lompatan' beberapa ADUN BN. BN kekal di Pahang dan Perlis manakala PAS kekal di Kelantan dan berjaya menawan Terengganu daripada BN. 'Gelombang' atau 'kuasa rakyat' yang dilihat berperanan sebagai 'silent voters' atau juga dikenali sebagai 'pengundi atas pagar' (40 peratus daripada keseluruhan 14.9 juta pengundi) ini membadai tanpa dapat dijangka oleh pengkaji/penganalisis politik sehinggalah pada hari pengundian iaitu 9 Mei 2018. Justeru adalah 
menjadi tujuan penulisan artikel ini untuk menganalisis 'gelombang' rakyat/pengundi dalam PRU 2018 ini.

\section{Sorotan literatur: Pilihan raya umum 2018}

Junaidi, Mohd Fuad \& Mohd Nizar (2018) menjelaskan bahawa kesemua parti politik berusaha sedaya upaya untuk memenangi hati pengundi 14,940,624 dalam PRU 2018. Parti politik ini menampilkan janji pilihan raya mereka melalui pelancaran manifesto pilihan raya sejak sebelum pembubaran Parlimen lagi disamping menyenaraikan trek rekod pemerintahan masing-masing di negeri dan nasional yang mereka kuasai. Mereka juga menjadikan isu nasional, isu negeri dan isu setempat sebagai modal untuk memancing undi terutamanya 40 peratus pengundi atas pagar dan pengundi muda yang belum menyatakan sokongan kepada mana-mana parti politik. Apa yang menariknya pada PRU kali ini ialah BN mengekalkan calon Perdana Menteri (PM) iaitu Dato' Sri Mohd Najib Razak yang dipalitkan dengan pelbagai isu oleh parti pembangkang; PH telah menamakan calon Perdana Menteri interim/sementara selama 2 tahun jika menang dalam PRU 2018 iaitu Tun Dr. Mahathir manakala buat pertama kali dalam sejarah penubuhan PAS bahawa parti tersebut bertanding melebihi 70 kerusi Parlimen iaitu 158 kerusi Parlimen ke arah pembentukan Kerajaan Teknokrat ataupun mereka akan menyertai kerajaan campuran selepas pilihan raya (post electoral coalision) jika gagal memenangi majoriti mudah 112 kerusi Parlimen dan juga pengenalan Budaya Politik Matang dan Sejahtera (BPMS) dan Wawasan Induk Negara Sejahtera (WINS) oleh PAS.

Kee (2018) menjelaskan bahawa fenomena 'euforia' atau takjub/teruja melanda rakyat Malaysia pasca PRU 2018 apabila buat pertama kali dalam sejarah 63 tahun politik di negara ini bahawa pakatan parti pembangkang iaitu PH berjaya menewaskan BN seterusnya menawan Putrajaya dan juga penampilan semula Tun Dr. Mahathir Mohamad yang berusia 92 tahun sebagai Perdana Menteri Malaysia buat kali kedua. Ooi (2018) menjelaskan bahawa faktor kegagalan BN mempertahankan kuasa di Putrajaya adalah kerana keputusan mengadakan hari pilihan raya pada hari Rabu iaitu hari bekerja yang menimbulkan kemarahan pengundi yang mengambil peluang untuk 'mengajar' BN pada PRU tersebut, kempen pilihan raya yang singkat yang memfokuskan pengundi untuk membuat keputusan politik dengan cepat tanpa berfikir panjang, penggantungan PPBM daripada sebarang aktiviti politik sehari sebelum hari penamaan calon menimbulkan rasa marah kepada ROS dan simpati pengundi kepada parti tersebut dan BN mengambil mudah jangkaan penganalisis politik kemungkinan besar akan berlaku 'Tsunami Melayu'. Gunasegaram (2018) menyatakan bahawa kegagalan Kerajaan/BN terutamanya Datuk Seri Mohd Najib menjawab persoalan isu 1MDB dengan jelas serta penyelesaian isu 1MDB dengan lambat disamping beberapa keputusan yang mencurigakan menyebabkan pengundi terusmenerus mempertikaikan isu ini dalam media sosial yang dilihat mempengaruhi pengundi yang berpendidikan tinggi, celik media sosial dan yang faham kronologi serta forensik 1MDB tersebut seterusnya mengambil keputusan untuk tidak menyokong BN.

Zinitulniza (2018) menyatakan bahawa 'Tsunami Pakatan' membadai PRU 2018 menyebabkan $\mathrm{PH}$ berjaya menewaskan $\mathrm{BN}$ dalam keadaan tidak dijangka. Setelah PH berjaya mengambil alih Kerajaan Pusat dibimbangi akan berlaku huru-hara kerana 63 tahun lamanya BN sudah menjadi Kerajaan Persekutuan dibimbangi penyokong BN terutamanya UMNO tidak dapat menerima hakikat kekalahan di luar jangkaan tersebut. Imlan (2018) menjelaskan bahawa PRU-14, 2018 yang digelar sebagai 'tsunami rakyat' turut dianggap 'ibu segala pilihan raya' di 
negara ini. Wibawa Tun Dr. Mahathir, isu cukai GST, skandal 1MDB, masalah kewangan FELDA, peningkatan kos sara hidup, peluang kerja yang terhad dan kebebasan bersuara yang dikekang menjadi faktor utama kekalahan BN dalam PRU 2018.

Mohammad Qayyum (2018a) menyatakan bahawa strategi PH menggunakan 1 logo iaitu logo PKR disamping pemilihan Tun Dr. Mahathir sebagai calon Perdana Menteri jika PH berjaya menawan Putrajaya dapat meyakinkan rakyat untuk membuat keputusan penting politik negara dengan memilih PH sebagai pemerintah di negara ini. Mohammad Qayyum (2018b) menghuraikan bahawa Malaysia terutamanya Orang Melayu perlu berbangga dengan Tun Dr. Mahathir Mohamad yang secara tidak langsung membantu menyatupadukan ahli politik dalam Pakatan Harapan untuk setuju menggunakan satu logo dan setuju sebagai calon Perdana Menteri adalah Tun Dr. Mahathir Mohamad yang menjadi resepi penting dalam memenangkan PH pada peringkat persekutuan dalam PRU 2018. Mohammad Qayyum (2018c) dalam buku beliau iaitu Anwar Ibrahim: Dari Penjara ke Istana menyatakan bahawa Anwar Ibrahim merupakan sorang figura politik yang sangat kental dan tabah dalam perjuangan politik beliau yang terkenal dengan kata-kata 'kalau takut kepada risiko/cabaran, usah bicara tentang perjuangan'.

Krishnamoorthy (2018) menyatakan bahawa Tun Dr. Mahathir Mohamad sebagai wira kerana menyelamatkan negara ini daripada terus berlaku korupsi. Bagi beliau, PRU-14, 2018 merupakan satu 'Tsunami Malaysia' yang berlaku kerana kuasa rakyat inginkan perubahan untuk membebaskan negara ini daripada pemerintahan BN yang digelar sebagai 'Kleptokrasi'. Faisal Syam (2018) menjelaskan PH dan WARISAN berjaya memperoleh 124 kerusi Parlimen (48.6 peratus), BN menang di 79 kerusi Parlimen (33.8 peratus) dan PAS menang di 18 kerusi (16.9 peratus). Beliau menyimpulkan bahawa pertandingan tiga penjuru tidak menguntungkan BN kerana berlakunya penolakan kuat terhadap politik berasaskan kaum, agama dan lokaliti; PH tidak menjangkakan akan mendapat keputusan yang baik di Sabah dan Sarawak terutamanya di kawasan majoriti Bumiputera; dan ketiga ialah majoriti penganalisis politik tidak menjangkakan bahawa akan berlaku perubahan kuasa politik rakyat di negara ini daripada BN kepada PH.

Mazlan (2018) menimbulkan persoalan iaitu 'Adakah tsunami hijau yang berlaku di negeri pantai timur dalam PRU-14 lalu disebabkan gelombang sokongan terhadap keabsahan perjuangan PAS atau wujudnya gelombang massa rakyat menyokong asalkan bukan UMNO-BN. Kemudian beliau menjelaskan faktor kemenangan PAS di Pantai Timur adalah berdasarkan beberapa perkara berikut iaitu 1) Ciri-ciri politik Terengganu (lokaliti/tempatan, kenal UMNO PAS, Orthodox Islamist Vs Bureaucratic Islamist/Conservative Islamis, 2) Doktrin agama (agama dan ideologi, hudud, RUU335, undi PH = undi DAP), 3) Isu nasional kelemahan polisi Najib Razak (1MDB, GST, kenaikan kos sara hidup dan rasuah), 4) Peranan Tun Dr. Mahathir Mohamad (rekod hitam Tun, sikap Tun terhadap Islam, bongkar Najib, kuda DAP), 5) Kebangkitan orang muda (celik politik/kerangka orthodox, tarikh mengundi rabu 9 hb = menapis pengundi dan sentimen anti Najib/UMNO), 6) Kekuatan jentera (PAS monopoli, kempen/jentera agresif, PAS juarai perang poster), dan 7) Dilema/krisis UMNO (sabotaj calon, wujud BERSATU/peranan Tun, politik wang/rasuah).

Mohd Agus (2018) menjelaskan bahawa soft power atau kuasa halus rakyat Malaysia yang merangkumi ahli pemikir, media, intelektual, gerakan sivil dan NGO telah bertindak melakukan perubahan untuk mengubah Kerajaan Persekutuan daripada BN kepada pakatan pembangkang iaitu Pakatan Harapan (PH) melalui bauran isu kos sara hidup, isu GST dan isu 1MDB. Ruhan Shahrir (2018) menjelaskan bahawa sebahagian besar undi Melayu-Islam dalam PRU 2018 berada di sebelah pihak pembangkang iaitu UMNO dan PAS manakala majoriti daripada ahli Parlimen PH (Kerajaan) adalah terdiri daripada bukan Melayu dan bukan Islam. 
Tunku Mohar (2018) menganalisis kajian yang berkaitan pilihan raya di Malaysia sejak pasca kemerdekaan (1957) hinggalah PRU 2018. Beliau menjelaskan bahawa terdapat kajian mengenai perubahan kerajaan dari sudut yang berbeza. Beliau juga menimbulkan persoalan mengenai kemenangan PH dalam PRU 2018 sama ada berpunca daripada kekuatan PH atau kelemahan BN. Mohd Zakaria \& Amer Saifude (2018) menjelaskan bahawa PRU 2018 menyaksikan gabungan parti pembangkang utama iaitu Pakatan Harapan telah menang dengan majoriti mudah disebabkan faktor ekonomi dan kepimpinan. Mohd Izzuddin \& Mohammad Agus (2018) merumuskan bahawa pengukuhan sokongan Bumiputera kepada BN di Sabah dan Sarawak dalam PRU-12 dan PRU-13 gagal diteruskan pada PRU-14 akibat peralihan besar sokongan pengundi Bumiputera terhadap $\mathrm{BN}$ kepada $\mathrm{PH}$. Ini telah mengakibatkan $\mathrm{BN}$ tumbang di peringkat persekutuan dan di Sabah. Kemorosotan ketara kerusi BN juga dapat dilihat di Sarawak. Terdapat beberapa faktor yang mendorong berlakunya perubahan tersebut seperti pemecatan Shafie Apdal dan penubuhan WARISAN, isu rasuah Kerajaan Persekutuan dan negeri, kegagalan Kerajaan BN menunaikan hak kedua-dua negeri dalam Perjanjian Malaysia 1963, dan kesepakatan yang wujud dalam Pakatan Harapan dan parti tempatan. Edwin, Chin \& Eng (2018) dalam kertas kerja yang bertajuk Analisis Mobilisasi Politik Pengundi Melayu dalam Pilihanraya Umum Ke 14 Malaysia menjelaskan bahawa akses komunikasi politik serta partisipasi politik dalam kawasan bandar yang terbuka luas dan tanpa sekatan jelas mempengaruhi corak pengundian kaum Melayu ini.

Muhamad Nadzri \& Jamaie (2018) menjelaskan bahawa penembusan terhadap kawasan Melayu/Bumiputera di kawasan separuh bandar dan luar bandar adalah kunci kepada strategi PH ke Putrajaya. Tanpa Mahathir, parti BERSATU dan WARISAN, laluan PH ke persekutuan akan menjadi lebih sukar dan PH mungkin tidak akan berjaya untuk memenangi PRU-14. Kemampuan BERSATU dan WARISAN merampas 21 kerusi daripada BN di kawasan itu telah mengukuhkan hujah ini. Kehadiran mereka dalam PH memberikan majoriti yang cukup diperlukan oleh pakatan pembangkang sejak PRU-12. Tetapi untuk meletakkan mereka sebagai satu-satunya faktor kemenangan, adalah sesuatu yang tidak tepat dan overrated. Suresh Kumar \& Sivarajan (2018) menghujahkan bahawa penolakan kaum India terhadap MIC dan juga Kerajaan BN amat jelas sejak PRU-12 lagi. Permasalahan kaum India yang tidak terselesai, kegagalan parti MIC dan kredibiliti calon MIC, kepimpinan Mahathir Mohamad, manifesto PH, peranan media sosial, peranan generasi muda dan peranan Hindraf mendorong peralihan besar undi kaum India kepada PH dalam PRU-14.

Junaidi, Abdul Muein \& Ahmad Afif (2018) mendapati bahawa tekad untuk jatuhkan BN, faktor ekonomi/beban/kos sara hidup rakyat, kerosakan imej atau personaliti/peribadi pemimpin dan parti, kesepaduan Pakatan Harapan, peranan media sosial, pengaruh Tun Dr. Mahathir, pengaruh 1.4 juta pengundi baru/muda dan perang persepsi telah berjaya membentuk satu gelombang yang akhirnya telah menumbangkan BN dalam PRU 2018. PH berjaya menewaskan BN dan PAS pada peringkat kerusi parlimen dengan 122-79-18. PH kekal di negeri Selangor dan Pulau Pinang serta berjaya menawan Johor, Negeri Sembilan, Melaka, Kedah, Perak dan Sabah ditawan PH dengan 'lompatan' beberapa ADUN BN. BN kekal di Pahang dan Perlis manakala PAS kekal di Kelantan dan berjaya menawan Terengganu daripada BN. PH menguasai wilayah Pantai Barat Semenanjung Malaysia disebabkan keyakinan pengundi terhadap gabungan parti pelbagai bangsa dan agama untuk memerintah negeri di wilayah tersebut; pengaruh Tun Dr. Mahathir; serta terpengaruh dengan sentimen negatif yang diterap melalui kempen media sosial dan ceramah bahawa 'undi PAS = undi BN'; dan sosialisasi politik Pantai Barat yang lebih mengutamakan aspek tadbir urus dan ekonomi. 
Mohd Azizuddin (2018) menjelaskan bahawa sebaik sahaja Malaysia masuk ke dalam politik liberal demokrasi, terutamanya dalam dekad ini, Malaysia kembali mengamalkan politik lama daripada konsosiasionalisme yang termotivasi oleh isu kaum dan agama. Selepas Mahathir Mohamad dipilih untuk mengetuai pembangkang Pakatan Harapan (PH) menentang rejim BN semasa dan memenangi PRU-14, politik Malaysia telah menunjukkan bahawa perbincangan/pandangan awam dapat mengatasi pandangan elit. Politik ketidakpastian dan politik perkauman ditolak oleh masyarakat Malaysia. Jelas sekali bahawa Malaysia bergerak ke arah politik yang baharu yang menjunjung demokrasi rasional dan suara rakyat mula didengari kerajaan semasa.

Edwin \& Chin (2018) menjelaskan bahawa sementara Pilihan Raya Umum ke-13 menyaksikan pembangkang menerima sokongan kuat di kawasan parlimen bandar dan Barisan Nasional pula terus mengekalkan dominasi kerusi parlimen di kawasan luar bandar, PRU-14, 2018 pula menyaksikan Barisan Nasional tewas dan gagal mencapai majoriti mudah untuk membentuk kerajaan. Nik Nazmi (2018) memberi sudut pandangan beliau dalam pembangunan politik gabungan parti pembangkang daripada kekecewaan PRU-13, 2013 kepada kegembiraan PRU-14, 2018. Beliau memerihalkan mengenai kejatuhan gabungan Pakatan Rakyat (PR) yang akhirnya membentuk Pakatan Harapan $(\mathrm{PH})$ dengan menceritakan pengalaman sebenar dan penglibatan beliau dalam 'bilik politik', persidangan parti, pembangunan INVOKE, bekerja dengan bekas Perdana Menteri (Tun Dr. Mahathir Mohamad), kempen PRU 2013 di Selangor dan PRU 2018 di Setiawangsa serta di Kelantan, Terengganu sehingga Baram, Sarawak yang akhirnya tercipta kemenangan mengasyikkan PH pada PRU 2018 yang menghasilkan kelahiran 'Malaysia Baharu'. Tricia (2018) menyatakan bahawa keputusan PRU 2018 adalah belum pernah terjadi dalam sejarah politik di negara kita. Rakyat Malaysia mengundi untuk perubahan terhadap penyandang iaitu BN. Pakatan Harapan yang terbentuk hasil daripada pakatan pembangkang yang merangkumi PKR, DAP, AMANAH dan BERSATU berjaya memenangi hati dan pemikiran rakyat dalam PRU tersebut.

Welsh (2018) menyatakan bahawa Teori 'RAHMAN' yang dimainkan penganalisis politik selama ini secara kebetulannya adalah tepat dengan ' $N$ ' merujuk kepada Najib yang merupakan pemimpin atau Perdana Menteri terakhir dalam dominasi politik UMNO/BN di negara ini. Beliau menghujahkan bahawa faktor pengkhianatan Najib yang terpalit dengan isu 1MDB menyebabkan BN tewas pada PRU 2018. Undi Melayu yang asalnya merupakan simpanan tetap UMNO/BN telah beralih arah kepada PAS dan sebahagian kecilnya berubah kepada PH menyebabkan undi Melayu terpecah kepada tiga parti politik tersebut. Junaidi et al. (2018) menghuraikan bahawa dalam PRU 2018 Malaysia menunjukkan bagi wilayah Pantai Barat Semenanjung Malaysia, Pakatan Harapan $(\mathrm{PH})$ yang bertanding menggunakan logo Parti Keadilan Rakyat (PKR) mendominasi kerusi Dewan Undangan Negeri (DUN) dan Parlimen berbanding Barisan Nasional (BN) dan Parti Islam Semalaysia (PAS). Junaidi (2018) menjelaskan bahawa apa yang menariknya keputusan dan pola pengundian PRU 2018 kali ini ialah kemenangan parti yang bertanding dibentuk daripada faktor geografi yang terpisah antara satu sama lain. PH secara majoritinya menang di wilayah atau zon Pantai Barat Semenanjung Malaysia terutamanya di kawasan bandar dan separa bandar manakala PAS menang di zon Pantai Timur Semenanjung Malaysia manakala BN kekal menguasai kawasan luar bandar terutamanya di negeri terkecil iaitu Perlis dan juga negeri terbesar di Semenanjung Malaysia iaitu Pahang.

Netusha (2018) menyatakan bahawa tanggal 9 Mei 2018 merupakan tarikh 'keramat' kerana pengundi di negara ini (Malaysia) teruja pulang ke tempat mengundi masing-masing 
untuk membuat pilihan politik bagi mencipta sejarah politik di negara ini. Pilihan raya tersebut telah meyakinkan mereka betapa pentingnya pengundian untuk memilih pemimpin negara. Akhirnya, Malaysia mengejutkan penganalisis politik pada saat demokrasi dilihat semakin lemah. Buat pertama kali dalam sejarah politik pilihan raya di negara ini bahawa BN telah tumbang setelah 63 tahun menguasai politik di negara ini.

Harold (2018) menyatakan bahawa isu GST, skandal 1MDB, FELDA FGV, pemimpin kleptokrasi dan sebagainya telah membuka mata pengundi di negara ini dengan penuh berani untuk menyelamatkan negara dengan mengundi parti pembangkang terutamanya $\mathrm{PH}$. Setelah $\mathrm{PH}$ menawan Putrajaya, adalah menjadi cabaran bagi memenuhi harapan rakyat, membetulkan keadaan untuk menghasilkan persekitaran politik 'Malaysia Baharu', belajar menjadi kerajaan setelah sekian lama berbudayakan politik kepembangkangan, bersedia menghadapi serangan politik persepsi dan bangkangan daripada BN dan PAS, menerap politik rasional dan berintegriti serta cuba sedaya upaya secepat yang boleh untuk memulihkan kerosakan ekonomi dan politik di negara ini sebaiknya. Muhamad Helmi \& Muhamad Nadzri (2018) menghuraikan bahawa pertembungan PAS dan AMANAH dalam PRU-14 telah memperlihatkan pecahan landskap politik Melayu-Islam dengan ketara dimana penerimaan dan penolakan terhadap ideologi PAS dan AMANAH dalam PRU-14 berlaku secara serentak di kawasan yang berbeza di Semenanjung Malaysia.

Kua (2019) menjelaskan bahawa kekalahan BN dalam PRU-14, 2018 belum pernah terjadi sebelumnya dalam sejarah politik pilihan raya di Malaysia. Anjakan memperlihatkan kejatuhan rejim BN menunjukkan berlakunya testimoni atau kesaksian bahawa keazaman rakyat Malaysia dan kegigihan masyarakat sivil dalam dekad yang amat lama selama 63 tahun untuk menamatkan penguasaan BN dalam politik pilihan raya di negara ini. Ahmad Lutfi (2019) menjelaskan bahawa tanggal 9 Mei 2018, Rabu diingati oleh seluruh rakyat Malaysia sebagai detik paling bersejarah. Rejim korup yang berkuasa selama enam dasawarsa sejak negara merdeka berjaya ditumbangkan dalam PRU14.

Junaidi \& Mazlan (2019) menjelaskan bahawa perjuangan parti politik dalam politik pilihan raya ada pasang-surutnya. Merujuk kepada prestasi UMNO dalam PRU 2018 jauh merosot berbanding PRU sebelumnya iaitu PRU 2013. AMANAH pula yang ditubuhkan pada tahun 2015 buat pertama kalinya menyertai PRU iaitu PRU 2018 terus mencapai prestasi yang memberangsangkan dengan berjaya memenangi banyak kerusi DUN dan Parlimen seterusnya berjaya menyertai kabinet Kerajaan Persekutuan dan beberapa Kerajaan Negeri. Dalam dunia politik tiada sesuatu yang mustahil, penuh dengan dinamika dan berseni/berstrategik. Matlamat perjuangan parti politik secara umumnya adalah untuk kebaikan rakyat namun dunia politik pilihan raya ini penuh dengan percaturan yang berstrategi dan bergantung kepada penerimaan pengundi terhadap isu dan kepimpinan dalam sesuatu parti politik. Justeru, UMNO dan AMANAH perlu terus berjuang dengan pendekatan dan pengalaman masing-masing demi kemaslahatan dan keharmonian rakyat di negara ini.

\section{Metod kajian}

Data kuantitatif dan maklumat kualitatif diperoleh dengan menggunakan metod rujukan sumber primer iaitu keputusan PRU 2018 manakala data sekunder pula diperoleh melalui rujukan sekunder terhadap bahan-bahan bercetak dan sumber atas talian yang berkenaan. Data keputusan 
PRU dan bahan daripada sumber sekunder digarap bersekali mengikut lunas akademik seterusnya menghasilkan penulisan analisis pilihan raya umum Malaysia 2018 yang berkesan.

\section{Hasil kajian dan perbincangan}

Keputusan PRU 2018

Suruhanjaya Pilihan Raya (SPR) mengumumkan keputusan penuh bagi kesemua 222 kerusi Parlimen selepas berakhir proses penjumlahan undi pada 4.45 pagi pada 10 Mei 2018. Barisan Nasional (BN) memperoleh 79 kerusi, PAS (18), PKR (104), DAP (9), Parti Warisan Sabah (8), Parti Solidariti Tanah Airku (1) dan Bebas (3). Secara keseluruhannya, jumlah peratusan pemilih yang keluar mengundi pada PRU-14 lalu adalah 82.32 peratus (12,299,514 orang) daripada jumlah keseluruhan pemilih berdaftar bagi PRU-14 iaitu 14,940,624 orang. PH berjaya menewaskan BN dan PAS pada peringkat kerusi parlimen dengan 122-79-18 (Lihat Rajah 1). PH kekal di negeri Selangor dan Pulau Pinang serta berjaya menawan Johor, Negeri Sembilan, Melaka; Kedah, Perak dan Sabah ditawan PH dengan 'lompatan' beberapa ADUN BN. BN kekal di Pahang dan Perlis manakala PAS kekal di Kelantan dan berjaya menawan Terengganu daripada BN. Dari segi perincian kerusi Parlimen yang dimenangi PH mengikut komponen, PKR menang di 49 kerusi (menjadi 52 kerusi setelah 3 MP Bebas iaitu 1 di WPKL dan 2 di Sarawak menyertai PKR selepas PRU 2018), DAP 42, PPBM 12, AMANAH 10 dan WARISAN 8 (menjadi 9 setelah MP BN bagi Tuaran menyertai WARISAN). Untuk keputusan PRU 2018 mengikut pecahan parti politik serta calon Bebas, negeri dan kerusi Parlimen serta DUN boleh dilihat dalam Jadual 1 dan Jadual 2.

Jadual 1. Pecahan calon Parlimen yang bertanding dan menang pada PRU 2018

\begin{tabular}{|c|c|c|c|c|c|c|c|c|c|}
\hline \multirow[t]{2}{*}{ Negeri } & \multirow{2}{*}{$\begin{array}{l}\text { Jumlah } \\
\text { kerusi } \\
\text { Parlimen }\end{array}$} & \multicolumn{2}{|c|}{$\begin{array}{ll}\text { PH } & \text { dan } \\
\text { WARISAN }\end{array}$} & \multicolumn{2}{|l|}{$\mathbf{B N}$} & \multicolumn{2}{|l|}{ PAS } & \multicolumn{2}{|c|}{ Bebas dan lain-lain } \\
\hline & & Tanding & Menang & Tanding & Menang & Tanding & Menang & Tanding & Menang \\
\hline Perlis & 3 & 3 & 1 & 3 & 2 & 3 & 0 & 0 & 0 \\
\hline Kedah & 15 & 15 & 10 & 15 & 2 & 15 & 3 & 2 & 0 \\
\hline Kelantan & 14 & 14 & 0 & 14 & 5 & 14 & 9 & 1 & 0 \\
\hline Terengganu & 8 & 8 & 0 & 8 & 2 & 8 & 6 & 0 & 0 \\
\hline Penang & 13 & 13 & 11 & 13 & 2 & 7 & 0 & 8 & 0 \\
\hline Perak & 24 & 24 & 13 & 24 & 11 & 21 & 0 & 2 & 0 \\
\hline Pahang & 14 & 14 & 5 & 14 & 9 & 14 & 0 & 5 & 0 \\
\hline WP & 13 & 12 & 10 & 13 & 2 & 9 & 0 & 5 & 1 \\
\hline Selangor & 22 & 22 & 20 & 22 & 2 & 20 & 0 & 11 & 0 \\
\hline N. 9 & 8 & 8 & 5 & 8 & 3 & 8 & 0 & 1 & 0 \\
\hline Melaka & 6 & 6 & 4 & 6 & 2 & 5 & 0 & 1 & 0 \\
\hline Johor & 26 & 26 & 18 & 26 & 8 & 20 & 0 & 2 & 0 \\
\hline Sabah & 25 & 25 & 18 & 25 & 10 & 9 & 0 & 38 & 1 \\
\hline Sarawak & 31 & 31 & 10 & 31 & 19 & 5 & 0 & 12 & 2 \\
\hline JUMLAH & 222 & 221 & 125 & 222 & 79 & 158 & 18 & 88 & 4 \\
\hline
\end{tabular}

Sumber: SPR, 2018 
Jadual 2. Pecahan calon DUN yang bertanding dan menang pada PRU 2018

\begin{tabular}{|c|c|c|c|c|c|c|c|c|c|}
\hline \multirow[t]{2}{*}{ Negeri } & \multirow{2}{*}{$\begin{array}{l}\text { Jumlah } \\
\text { kerusi } \\
\text { DUN }\end{array}$} & \multicolumn{2}{|c|}{$\begin{array}{ll}\text { PH } & \text { dan } \\
\text { WARISAN } & \\
\end{array}$} & \multicolumn{2}{|l|}{ BN } & \multicolumn{2}{|l|}{ PAS } & \multicolumn{2}{|c|}{ Bebas dan lain-lain } \\
\hline & & Tanding & Menang & Tanding & Menang & Tanding & Menang & Tanding & Menang \\
\hline Perlis & 15 & 15 & 3 & 15 & 10 & 15 & 1 & 1 & 0 \\
\hline Kedah & 36 & 36 & 18 & 36 & 3 & 36 & 15 & 8 & 0 \\
\hline Kelantan & 45 & 43 & 0 & 45 & 8 & 45 & 37 & 8 & 0 \\
\hline Terengganu & 32 & 32 & 0 & 32 & 10 & 32 & 22 & 0 & 0 \\
\hline Penang & 40 & 39 & 37 & 40 & 2 & 21 & 1 & 55 & 0 \\
\hline Perak & 59 & 59 & 29 & 59 & 27 & 44 & 3 & 9 & 0 \\
\hline Pahang & 42 & 42 & 9 & 42 & 25 & 41 & 8 & 6 & 0 \\
\hline Selangor & 56 & 56 & 51 & 56 & 4 & 47 & 1 & 31 & 0 \\
\hline N. 9 & 36 & 35 & 20 & 36 & 16 & 27 & 0 & 7 & 0 \\
\hline Melaka & 28 & 28 & 15 & 28 & 13 & 24 & 0 & 5 & 0 \\
\hline Johor & 56 & 55 & 36 & 56 & 19 & 41 & 1 & 6 & 0 \\
\hline Sabah & 60 & 60 & 29 & 60 & 29 & 18 & 0 & 113 & 2 \\
\hline JUMLAH & 505 & 500 & 247 & 505 & 166 & 391 & 90 & 249 & 2 \\
\hline
\end{tabular}

Sumber: SPR, 2018

\section{Tekad untuk jatuhkan BN dan Datuk Seri Najib}

Pasca PRU 2018 memperlihatkan faktor yang paling utama yang menjadi kekalahan BN pada peringkat Pusat dan negeri-negeri Johor, Perak, Melaka, Negeri Sembilan, Kedah dan Sabah ialah tekad untuk menjatuhkan BN. Dalam mindset pengundi adalah yang menjadi keutamaan pertimbangan mereka untuk mengundi pada PRU 2018 ini ialah menjatuhkan/menumbangkan BN terlebih dahulu. Ini bermakna mereka akan memilih parti selain BN sama ada PH atau PAS. Pengundi sudah tidak peduli terhadap faktor manifesto, faktor calon, faktor isu setempat dan isu nasional, faktor kempen oleh jentera, faktor janji pilihan raya dan sebagainya. Apa yang penting bagi mereka adalah menjatuhkan $\mathrm{BN}$ dan Najib terlebih dahulu kemudian mengubah sistem pemerintahan dan membaiki struktur ekonomi mikro dan makro. BN dilihat oleh rakyat sebagai sudah terlalu lama berkuasa, tidak dapat menerima kritikan, memeras keringat rakyat (GST), berlaku penyelewengan dan ketirisan serta mementingkan kroni dan nepotisme dan kepentingan diri pemimpin sendiri. Justeru, rakyat inginkan perubahan terhadap kerajaan dan sistem yang baru serta tidak memeras rakyat dalam menjalankan dan menjayakan program pembanngunan dan kemajuan negara ini.

\section{Faktor kemelesetan ekonomi negara}

Antara faktor kekalahan $\mathrm{BN}$ pada peringkat nasional ialah faktor kemelesetan ekonomi/beban/kos sara hidup serta isu GST terutamanya di kawasan bandar. Isu yang paling dekat di hati dan dalam kehidupan seharian rakyat ialah isu ekonomi terutamanya ekonomi mikro/keluarga. Isu ini amat terkesan kerana dalam kehidupan ini, kewangan dan perbelanjaan akan mempengaruhi emosi, persepsi dan kesejahteraan serta keharmonian dan ketenangan hidup sama ada sebagai individu dan berkeluarga. Isu ekonomi juga berkait dengan beberapa perkara terutamanya keperluan asas hidup iaitu makanan, pakaian dan tempat tinggal. Kemudian jika ada lebihan duit barulah boleh dibelanjakan untuk kehendak atau gaya hidup atau taste masingmasing untuk kepuasan hidup, status dan ego hidup yang tinggi. Dalam konteks kehidupan seharian, rakyat mengharapkan kerajaan atau pemerintah dapat mewujudkan suasana ekonomi 
yang kondusif, berdaya saing, bersubsidi dan bantuan yang bersifat merakyat dan menjaga kebajikan rakyat mengikut golongan sasar tertentu yang berbeza keutamaan keperluannya seperti golongan muda, golongan dewasa, golongan tua, golongan pesara, golongan minoriti, golongan B40 (below/berpendapatan rendah 40\% daripada keseluruhan komposisi penduduk), golongan M40 (medium/berpendapatan sederhana 40\% daripada keseluruhan komposisi penduduk), golongan T20 (top/berpendapatan tinggi 20\% daripada keseluruhan komposisi penduduk) dan lain-lain. Dalam menangani keperluan dan kehendak rakyat yang dihuraikan di atas dilihat oleh rakyat bahawa $\mathrm{BN}$ gagal menangani isu ekonomi untuk rakyat bagi jangka panjang.

Isu cukai GST pula dilihat oleh rakyat bahawa Kerajaan BN 'memeras' atau mengerah rakyat untuk membantu kerajaan dalam memajukan negara ini. Rakyat tidak dapat menerima penjelasan Kerajaan BN sebelum ini bahawa tujuan rakyat dikenakan GST ialah 'daripada rakyat, untuk rakyat'. Rakyat juga merasakan dipermainkan apabila BN menyatakan bahawa hasil GST daripada rakyat dipulangkan kepada rakyat dalam bentuk bantuan BR1M, pembangunan infrastruktur, projek mega dan bantuan kebajikan lain kepada rakyat. Hal ini ditambah lagi dengan subsidi petrol yang dihapuskan. Rakyat tidak boleh menerima pendekatan BN ini. Bagi rakyat, adalah menjadi tugas atau tanggungjawab Kerajaan/BN untuk membangunkan negara ini tanpa mengerah/menyusahkan rakyat melalui GST dan penghapusan subsidi tertentu kerana rakyat telah memilih mereka dalam PRU. Bagi rakyat, adalah menjadi tugas Kerajaan/BN untuk menambahkan pendapatan negara dengan cara selain mengerah rakyat melalui cukai tertentu. Bagi mereka/rakyat, untuk menjana pendapatan negara, Kerajaan/BN perlu berusaha menarik pelabur asing untuk melabur di negara ini, meneroka sumber alam semaksimum mungkin, galakan eksport dan tindakan-tindakan ekonomi lain yang boleh mendatangkan pendapatan kepada negara. Justeru, Kerajaan Pusat/BN dilihat gagal membela rakyat dalam soal ekonomi dan ini menjadikan BN tertolak buat pertama kalinya dalam sejarah politik negara ini.

\section{Kesimpulan}

Sebagai kesimpulannya, politik adalah satu disiplin ilmu yang menarik tetapi sukar untuk dikaji kerana tingkah laku politik pengundi adalah dinamik atau tidak statik, bahkan boleh berubah dengan mengejut. Aktor politik iaitu pemain politik sama ada pemimpin mahupun parti politik tidak boleh memperkecilkan 'kuasa rakyat' yang boleh mengubah keadaan dengan sekelip mata sahaja. Pemimpin dan parti politik boleh mengatur pelbagai strategi dari segi kempen dan gerak kerja parti untuk memenangi hati pengundi namun gelombang atau kuasa rakyat sesekali tidak dapat dibendung lagi. Pelbagai analisis dari sudut isu, jangkaan kemenangan faktor kemenangan dan kekalahan, pola pengundian dan dan impak politik boleh dibuat namun kuasa politik pengundi dan ketentuanNya tidak dapat dihalang oleh sesiapapun. Rakyat telah bersuara dan memilih apa yang mereka kehendaki. Oleh itu, semua pihak perlu menerima apa jua keputusan secara terbuka dan menghormati kehendak dan pilihan rakyat. Dalam negara demokrasi, rakyatlah yang menentukan pemerintahan sesebuah negara. Rakyat telah membuat penilaian dan telah memilih kerajaan yang mereka kehendaki. Justeru, semua pihak perlu menerima keputusan politik rakyat Malaysia ini dengan hati yang terbuka. Pihak yang menang perlu melaksanakan janji yang termaktub dalam manifesto parti masing-masing manakala pihak yang kalah perlu bermuhasabah, membetulkan kesilapan diri atau organisasi dan boleh bertanding lagi pada PRU akan datang. Apa yang penting disini ialah suara dan kebajikan rakyat perlu diambil berat oleh 
semua pihak untuk memastikan hidup bernegara ini dengan lebih tenang, harmoni dan sejahtera hendaknya.

\section{Rujukan}

Ahmad Lutfi Othman. (2019). Revolusi tanpa darah: Keberanian rakyat Malaysia tumbangkan rejim kleptokrat UMNO-BN dalam PRU14. Ampang: Penerbit Ahmad Lutfi Othman.

Edwin Michael \& Chin Yee Mun. (2018, August). Sosialisasi Politik Dalam Kehidupan Politik Etnik Cina di Malaysia: Satu Kajian Literatur. The Eleventh International Malaysian Studies Conference (MSC11). Langkawi, Kedah.

Edwin Michael, Chin Yee Mun \& Eng May Chuen. (2018, November). Analisis Mobilisasi Politik Pengundi Melayu dalam Pilihanraya Umum Ke 14 Malaysia. International Conference on Social Sciences And Humanities (ICOSH-7) 2018. Fakulti Sains Sosial dan Kemanusiaan (FSSK), Universiti Kebangsaan Malaysia (UKM), Bangi, Selangor.

Faisal Syam Abdol Haziz. (2018). GE14: The political earthquake that ended BN's 60 year rule. In Francis Loh \& Anil Netto (Eds), Regime change in Malaysia: GE14 and The end of UMNO-BN'S 60-year rule. Petaling Jaya: Strategic Information and Research Development Centre.

Gunasegaram, P. (2018). 1MDB: The scandal that brought down a government. Petaling Jaya: Strategic Information and Research Development Centre.

Harold Jangus. (2018). May $9^{\text {th }}$ 2018: The day malaysians finally opened their eye and saved the nation!. Puchong: Vinlin Press Sdn Bhd.

Imlan Adabi. (2018). Penangan tsunami rakyat untuk BN muhasabah diri. Dewan Masyarakat. Bil. 6. Halaman 8-17.

Junaidi Awang Besar \& Mazlan Ali. (2019, Julai). UMNO dan Parti Amanah Negara (Amanah): Analisis Prestasi Dalam PRU 2018 dan Pasca PRU 2018. Seminar Antarabangsa Ke-8 Arkeologi, Sejarah, Bahasa dan Budaya di Alam Melayu (ASBAM 8, 2019). Port Dickson, Negeri Sembilan, Malaysia.

Junaidi Awang Besar, Abdul Muein Abadi \& Ahmad Afif Zulkipli. (2018, Julai). Gelombang rakyat dalam Pilihan Raya Umum (PRU) Ke-14, 2018 di Malaysia. Seminar Antarabangsa Ke-7, Arkeologi, Sejarah dan Budaya di Alam Melayu (ASBAM 7, 2018). Jayakarta, Nusa Tenggara Barat, Indonesia.

Junaidi Awang Besar, Mohd Fuad Mat Jali \& Mohd Nizar Sudin. (2018, August). Pilihan Raya Umum Ke-14, 2018: Analisis Terhadap Persaingan Antara BN, PH, PAS dan Parti-Parti Politik Lain. The $12^{\text {th }}$ International Conference on Malaysia-Indonesia Relations (PAHMI12, 2018). Fakulti Sastera dan Sains Sosial, Universiti Malaya, Kuala Lumpur, Malaysia.

Junaidi Awang Besar, Mohd Fuad Mat Jali, Rosmadi Fauzi, Mohd Syukri Zainuddin, Muhammad Hazim Abd Ghani \& Mazlan Ali. (2018, November). Pola Pengundian Dalam Pilihan Raya Umum Ke-14, 2018 di Wilayah Pantai Barat Semenanjung Malaysia. Malaysia Brunei Forum 2018 (MBF 2018). Fakulti Sastera dan Sains Sosial, Universiti Malaya, Kuala Lumpur, Malaysia.

Kee Thuan Chye. (2018). The people's victory: How Malaysians saved their country. Singapore: Marshall Cavendish Editions.

Krishnamoorthy, M. (2018). May 9 people power saves Malaysia: Mahathir leads the way. Petaling Jaya: Krishnamoorthy Muthali. 
Kua Kia Soong. (2019). Days of Hope: Real Reform for 'New' Malaysia. Petaling Jaya: SUARAM.

Mazlan Ali. (2018, Jun). "Tsunami hijau Pantai Timur PRU-14: Gelombang PAS atau gelombang rakyat?”. Forum Pasca PRU14: Gelombang Rakyat. Aras 13, Menara SAAS UiTM Shah Alam.

Mohammad Qayyum A. Badaruddin. (2018a). Sumpahan Teori RAHMAN: Musibah dari tragedi $P R U$-14. Cheras: Casamas Resourses Sdn. Bhd.

Mohammad Qayyum A. Badaruddin. (2018b). Tun Mahathir: Menongkah arus menerjah limitasi. Cheras: Casamas Resourses Sdn. Bhd.

Mohammad Qayyum A. Badaruddin. (2018c). Anwar Ibrahim: Dari penjara ke istana. Cheras: Casamas Resourses Sdn. Bhd.

Mohd Agus Yusof. (2018, Mei). Pasca-PRU14: Ke Mana Kita Selepas Ini?. Bicara Persada ke44 UKM (Siri Wacana Pasca-PRU14). Persada Canselori UKM.

Mohd Azizuddin Mohd Sani. (2018, August). The emergence of new politics in Malaysia revisited. The Eleventh International Malaysian Studies Conference (MSC11). Langkawi, Kedah.

Mohd Izzuddin Nazaruddin \& Mohammad Agus Yusoff. (2018, November). Pengaruh pengundi bumiputera terhadap perubahan politik di Sabah dan Sarawak dalam PRU 14. International Conference on Social Sciences And Humanities (ICOSH-7) 2018. Fakulti Sains Sosial dan Kemanusiaan (FSSK), Universiti Kebangsaan Malaysia (UKM), Bangi, Selangor.

Mohd Zakaria Ibrahim \& Amer Saifude Ghazali. (2018, November). Ayunan sokongan rakyat Malaysia dalam Pilihanraya Umum 1999-2018. Malaysia Brunei Forum 2018 (MBF 2018). Fakulti Sastera dan Sains Sosial, Universiti Malaya, Kuala Lumpur, Malaysia.

Muhamad Helmi Sabtu \& Muhamad Nadzri Mohamed Noor. (2018). Persaingan ideologi PAS dan AMANAH dalam politik dan pilihan raya. Bangi: Penerbit Universiti Kebangsaan Malaysia.

Muhamad Nadzri Mohamed Noor \& Jamaie Hj. Hamil. (2018). Politik, Pengundi dan Faktor Melayu/Bumiputera: Analisis Terhadap Kegagalan Barisan Nasional dalam PRU 2018. Jebat: Malaysian Journal of History, Politics \& Strategic Studies, 45(2), 386-408.

Netusha Naidu. (2018). 'Critical Optimism' Lights Malaysia's way forward. In Tang Ah Chai, Imran Mohd Rasid, Jeremy Lim Jiang Shen \& Yvonne Tan Yit Fong (Eds). 509: The people have spoken. Petaling Jaya: Strategic Information and Research Development Centre.

Nik Nazmi Nik Ahmad. (2018). 9 May 2018: Notes from the frontline. Petaling Jaya: Strategic Information and Research Development Centre.

Ooi Kee Beng. (2018). Catharsis: A second chance for democracy in Malaysia. Petaling Jaya: Strategic Information and Research Development Centre.

Ruhan Shahrir Abdul Halim. (2018). Pakatan Harapan tewas undi Melayu: Implikasinya pada masa hadapan. Siri Seminar IKMAS 6/2018. Bangi.

Suresh Kumar N Vellymalay \& Sivarajan Ponniah. (2018). Tsunami India dalam Pilihan Raya Umum Ke-14: Peralihan sokongan daripada politik etnik kepada politik multietnik. Jebat: Malaysian Journal of History, Politics \& Strategic Studies, 45(2), 206-231.

Tricia Yeoh. (2018). Notes on a new nation, day 1 post-GE14. In Tang Ah Chai, Imran Mohd Rasid, Jeremy Lim Jiang Shen \& Yvonne Tan Yit Fong (Eds). 509: The people have spoken. Petaling Jaya: Strategic Information and Research Development Centre. 
Tunku Mohar Tunku Mohd. Mokhtar. (2018, June). Studying elections in Malaysia: Focus on GE14. Seminar on G14: An Analysis. UIAM, Gombak.

Welsh, B. (2018), Hantu Raya: UMNO's Dead End Politics. In B. Welsh (ed.), The End of UMNO: Essays on Malaysia's Former Dominant Party (pp. 345-380), Petaling Jaya: SIRD Publications.

Zinitulniza Abdul Kadir. (2018). Amanah Mohamad Sabu. Kuala Lumpur: Institut Terjemahan dan Buku Malaysia. 